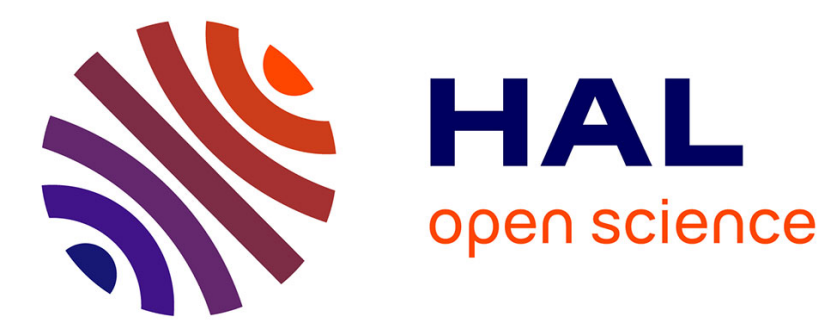

\title{
Synergistic effects in ambiphilic phosphino-borane catalysts for the hydroboration of $\mathrm{CO} \_2_{2}$
}

Anis Tlili, Arnaud Voituriez, Angela Marinetti, Pierre Thuéry, Thibault Cantat

\section{- To cite this version:}

Anis Tlili, Arnaud Voituriez, Angela Marinetti, Pierre Thuéry, Thibault Cantat. Synergistic effects in ambiphilic phosphino-borane catalysts for the hydroboration of CO_2. Chemical Communications, 2016, 52, pp.7553-7555. 10.1039/c6cc02809h . cea-01329300

\section{HAL Id: cea-01329300 https: / hal-cea.archives-ouvertes.fr/cea-01329300}

Submitted on 15 Feb 2019

HAL is a multi-disciplinary open access archive for the deposit and dissemination of scientific research documents, whether they are published or not. The documents may come from teaching and research institutions in France or abroad, or from public or private research centers.
L'archive ouverte pluridisciplinaire HAL, est destinée au dépôt et à la diffusion de documents scientifiques de niveau recherche, publiés ou non, émanant des établissements d'enseignement et de recherche français ou étrangers, des laboratoires publics ou privés. 


\title{
Synergistic Effects in Ambiphilic Phosphino- Borane Catalysts for the Hydroboration of $\mathrm{CO}_{2}$
}

\author{
Anis Tlili, a,b Arnaud Voituriez, ${ }^{b *}$ Angela Marinetti, ${ }^{b *}$ Pierre Thuérya and \\ Thibault Cantat ${ }^{\text {a }}$
}

The benefit of combining both a Lewis acid and a Lewis base in a catalytic system has been established for the hydroboration of $\mathrm{CO}_{2}$, using ferrocene-based phosphine, borane and phosphino-borane derivatives.

Featuring a carbon atom at the $+\mathrm{IV}$ oxidation state, $\mathrm{CO}_{2}$ is a stable molecule and its conversion to either fuels or chemicals necessitates the use of a mild reductant and an efficient catalyst, to promote the cleavage of $\mathrm{C}-\mathrm{O}$ bonds and the formation of novel $\mathrm{C}-\mathrm{H}$ and/or $\mathrm{C}-\mathrm{C}$ bonds. ${ }^{1}$ In this respect, hydroboranes $\left(\mathrm{R}_{2} \mathrm{BH}\right)$ have a mild reduction potential (ca. $-0.5 \mathrm{~V} v s$ NHE) well-suited for the reduction of $\mathrm{CO}_{2}$ to the methanol level. ${ }^{2}$ In contrast to borohydrides, the reduction of $\mathrm{CO}_{2}$ with hydroboranes requires a catalyst. ${ }^{3}$ In fact, the catalytic hydroboration of $\mathrm{CO}_{2}$ has first been reported in 2010 by Guan and coworkers who showed that nickel(II) pincer complexes were able to catalyze the reduction of $\mathrm{CO}_{2}$ to methoxyboranes in the presence of 9-BBN, catBH and pinBH. ${ }^{4}$ Shortly after, Sabo-Etienne and Bontemps described efficient ruthenium catalysts for this transformation and a variety of inorganic and organometallic catalysts have been reported since then. ${ }^{5}$ Notably, the polarized $\mathrm{B}-\mathrm{H}$ bond in hydroboranes can also be activated by simple organic compounds: the organocatalyzed hydroboration of $\mathrm{CO}_{2}$ has been unveiled in 2013 by Fontaine and coworkers with P/B Frustrated Lewis Pairs (FLPs), and by our group with guanidines and amidines bases as well as using an isolated FLP-CO 2 adduct. ${ }^{6}$ This collection of catalysts has been completed with several bases among which phosphines proved to be potent catalysts for this reduction process. ${ }^{7}$ In this context, we have also shown recently that proazaphosphatranes enable the first catalytic methylation of amines involving $\mathrm{CO}_{2}$ reduction with hydroboranes. ${ }^{7 \mathrm{a}}$ Thus, since the hydroboration of $\mathrm{CO}_{2}$ is a reaction of fundamental importance, it becomes crucial now to better apprehend the role of the organocatalysts in these reduction processes. In particular, the possible positive influence of combining a Lewis base with a Lewis acid in the same catalytic system is still to be established.

To address this question, we report herein the synthesis of simple phosphine, borane and phosphino-borane compounds based on the same ferrocene backbone (Chart 1). Comparing the catalytic performances of the separated Lewis acids and bases and their combination as intermolecular or intramolecular systems demonstrates the benefits of the ambiphilic systems, for the first time.

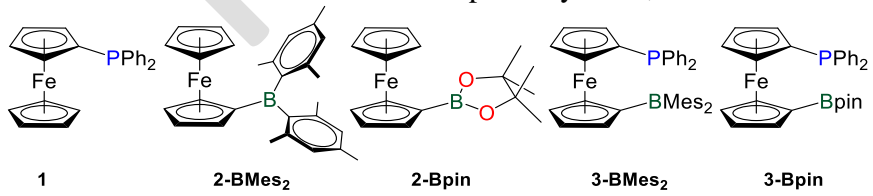

Chart 1. Candidates for the catalytic hydroboration of $\mathrm{CO}_{2}$

The ferrocene backbone is a well-suited platform to assemble Lewis acids and bases by substituting the cyclopentadienyl ligands on iron. This approach has been exemplified over the last years by the groups of Bourissou, Aldridge and Erker to access novel FLPs and ambiphilic ligands. ${ }^{8}$ Additionally, rotation around the ferrocene axis provides some flexibility that can adapt the catalyst to the geometric constraints associated with the catalytic pathway. In this respect, ferrocene based FLPs differ from the system used by Fontaine et al. for the hydroboration of $\mathrm{CO}_{2}$, where a benzene ring maintains a rigid structure between the $\mathrm{P}$ and $\mathrm{B}$ centres. ${ }^{6 \mathrm{a}}$

In this study, diphenylphosphinoferrocene, $1,{ }^{9 a}$ was isolated by quenching the lithiated ferrocene ${ }^{9 b}$ with chlorodiphenylphosphine (Scheme 1). Similarly, the corresponding ferrocenyl-pinacolborane 2Bpin was obtained in a moderate $25 \%$ yield by reacting bis(pinacolato)diboron with lithiated ferrocene. Crystals of 2-Bpin were obtained by recrystallization from dichloromethane (see ESI). When dimesitylboron fluoride was used as an electrophile, 2-BMes2 was obtained in a significantly better yield of $71 \%$ (Scheme 1).

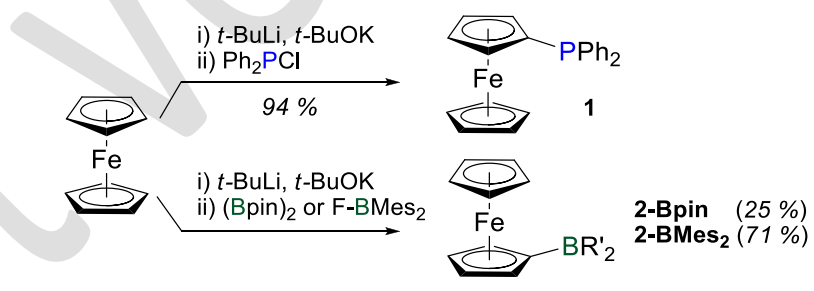

Scheme 1. Synthesis of 1, 2-Bpin and 2-BMes 2

The phosphino-borane derivatives 3-Bpin and 3-BMes2 were prepared using an established procedure based on a sequential halogen/lithium exchange starting from 1,1'-dibromoferrocene (Scheme 2). ${ }^{8 a}$ Thus, 1-bromo-1'-(diphenylphosphino)ferrocene 4 was obtained in $87 \%$ isolated yield. Subsequently, a second bromine/lithium exchange was conducted and the lithiated ferrocene was quenched with bis(pinacolato)diboron, yielding the desired product 3-Bpin in a low $18 \%$ yield. Other pinacol-boron electrophiles including 2-isopropoxy-4,4,5,5-tetramethyl-1,3,2dioxaborolane, were also tested, without success. Alternative routes were explored to improve the yields of 3-Bpin. Unfortunately, inverting the reaction sequence by quenching 1-bromo-1'-lithioferrocene with bis(pinacolato)diboron first proved unproductive. Also, quenching $\mathbf{4}$ with trimethyl borate and subsequent reaction with pinacol failed. 


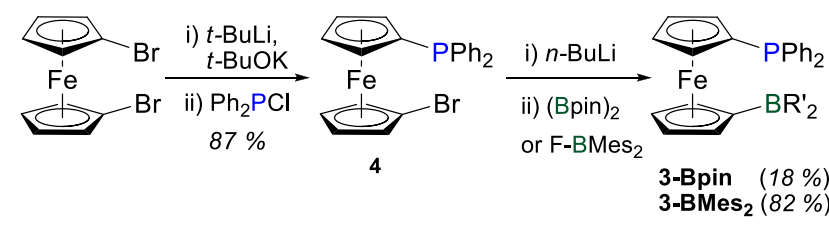

Scheme 2. Synthesis of 3-Bpin and 3-BMes

As reported by Bourissou et al., replacing bis(pinacolato)diboron with dimesitylboron fluoride yielded 3-BMes2 in $82 \%$ yield. ${ }^{8 a}$ It is noteworthy that the $\mathrm{P} / \mathrm{B}$ derivatives 3-BMes2 and 3-Bpin display ${ }^{31} \mathrm{P}$ NMR chemical shifts similar to those of (diphenylphosphino)ferrocene $(\mathbf{1}: \delta=-16.2 ; 3$-Bpin: $\delta=-17.4 ; 3$ BMes2: $\delta=-19.3 \mathrm{ppm})$. This suggests the absence of any interaction between the two heteroatoms, as noted previously by Bourissou et al. Moreover, no interaction with $\mathrm{CO}_{2}$ has been observed either by ${ }^{31} \mathrm{P}$ or ${ }^{1} \mathrm{H}$ NMR, when a solution of 3-BMes2 is exposed to an atmosphere of $\mathrm{CO}_{2}{ }^{10}$

Having in hand a homogeneous series of P-, B- and P/B-based catalysts, their reactivity has been investigated in the catalytic hydroboration of $\mathrm{CO}_{2}$. At room temperature, phosphine 1 (1 mol\%) exhibits a negligible catalytic activity in the conversion of $\mathrm{CO}_{2}$ and 9borabicyclo[3.3.1]nonane (9-BBN) to methoxyborane MeO-BBN (Table 1, Entry 1). Indeed a Turn Over Number (TON) lower than 5 was observed after $28 \mathrm{~h}$ at $25^{\circ} \mathrm{C}$. Increasing the reaction temperature to $70{ }^{\circ} \mathrm{C}$ did not improve the catalytic performances of $\mathbf{1}$ (Entry 11 in Table 1). These results are in line with the results of Stephan et al. on the phosphine catalysed hydroboration of $\mathrm{CO}_{2}{ }^{7 \mathrm{~b}}$ Similarly, the borane 2-BMes2 is inefficient both at 25 and $70{ }^{\circ} \mathrm{C}$ (Entries 2 and 12 in Table 1). In stark contrast, a mixture of $\mathbf{1}$ and 2-BMes2 provides a competent catalytic system, enabling the reduction of $\mathrm{CO}_{2}$ to $\mathrm{MeOBBN}$ with a TON of 41 after $28 \mathrm{~h}$ at $25^{\circ} \mathrm{C}\left(\mathrm{TOF}=1.5 \mathrm{~h}^{-1}\right)$. This result demonstrates for the first time the synergistic and positive influence of combining a Lewis base and a Lewis acid in the reduction of $\mathrm{CO}_{2}$ with hydroboranes. Replacing 2-BMes2 with the less acidic 2-Bpin borane somewhat deactivates the catalytic system and a TON of 36 $\left(\mathrm{TOF}=1.3 \mathrm{~h}^{-1}\right)$ is measured under the same conditions. To further establish the benefit of an ambiphilic structure, the catalytic potential of the intramolecular Lewis pairs 3-BMes2 and 3-Bpin has been determined. 3-BMes2 presents a better activity than the mixture of $\mathbf{1}$ and 2-BMes2 and a TON of 100 was reached after 28 hours at $25^{\circ} \mathrm{C}$ $\left(\mathrm{TOF}=3.6 \mathrm{~h}^{-1}\right)$.

It is worth noting here, that the reaction course follows a profile similar to the one observed previously for guanidines and N/B FLPs. ${ }^{6}{ }^{6}$ Indeed, monitoring the product distribution over time, using ${ }^{1} \mathrm{H}$ and ${ }^{13} \mathrm{C}$ NMR spectroscopy, reveals that $\mathrm{CO}_{2}$ is first reduced to the boryl formate HCOO-BBN which is present in only a very low concentration and does not accumulate (Fig. S1). This intermediate is subsequently reduced to the acetal form $\mathrm{H}_{2} \mathrm{C}(\mathrm{OBBN})_{2}$, with a conversion rate of $90 \%$ after just 1 hour. Finally, reduction of the acetal provides $\mathrm{MeO}-\mathrm{BBN}$. This step is slow and requires 27 hours at $25{ }^{\circ} \mathrm{C}$ to yield the methoxyborane species quantitatively. The kinetics of the reaction improved at $70{ }^{\circ} \mathrm{C}$. These conditions revealed a remarkable catalytic activity of 3-BMes2, allowing the full conversion of $\mathrm{CO}_{2}$ to the corresponding methoxyborane with a TON of 100, in only 2 hours (Table 1 , entry 7). Reducing the loading of catalyst 3BMes2 to 0.1 and $0.05 \mathrm{~mol} \%$, afforded an excellent TON of 1980 , after $20 \mathrm{~h}$ at $70{ }^{\circ} \mathrm{C}$, and a TOF of $250 \mathrm{~h}^{-1}$, while the isolated components of the catalytic system, namely 1 and 2-BMes2, are unreactive (Table 1, Entries 9-12).
Table 1. Catalytic reduction of $\mathrm{CO}_{2}$ to methoxyborane $\mathrm{CH}_{3} \mathrm{OBBN}$

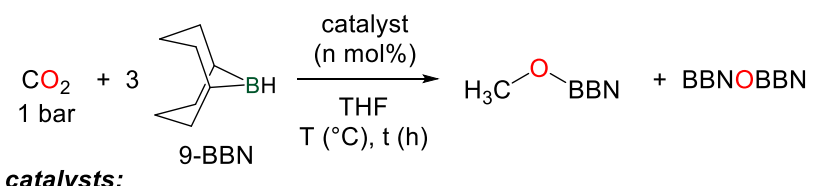

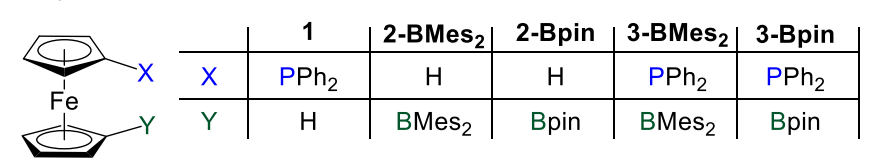

\begin{tabular}{|c|c|c|c|c|c|}
\hline Entry $^{\mathrm{a}}$ & $\begin{array}{l}\text { Catalyst } \\
(\mathrm{mol} \%)\end{array}$ & $\mathrm{T}^{\circ} \mathrm{C}$ & $\begin{array}{c}\text { Time } \\
\text { (h) }\end{array}$ & $\mathrm{TON}^{\mathrm{b}}$ & $\begin{array}{l}\text { TOF } \\
\left(h^{-1}\right)^{b}\end{array}$ \\
\hline 1 & $\mathbf{1}(1 \mathrm{~mol} \%)$ & $25^{\circ} \mathrm{C}$ & $28 \mathrm{~h}$ & $<5$ & $<0.2$ \\
\hline 2 & 2-BMes 2 (1 mol\%) & $25^{\circ} \mathrm{C}$ & $28 \mathrm{~h}$ & 0 & 0 \\
\hline 3 & 3-Bpin ( $1 \mathrm{~mol} \%)$ & $25^{\circ} \mathrm{C}$ & $28 \mathrm{~h}$ & 84 & 3.0 \\
\hline 4 & 3-BMes 2 (1 mol\%) & $25^{\circ} \mathrm{C}$ & $28 \mathrm{~h}$ & 100 & 3.6 \\
\hline 5 & $\begin{array}{l}1(1 \mathrm{~mol} \%) \\
+\mathbf{2} \text {-Bpin }(1 \mathrm{~mol} \%)\end{array}$ & $25^{\circ} \mathrm{C}$ & $28 \mathrm{~h}$ & 36 & 1.3 \\
\hline 6 & $\begin{array}{l}1(1 \mathrm{~mol} \%) \\
+\mathbf{2}-\mathbf{B M e s}_{2}(1 \mathrm{~mol} \%)\end{array}$ & $25^{\circ} \mathrm{C}$ & $28 \mathrm{~h}$ & 41 & 1.5 \\
\hline 7 & 3-BMes 2 (1 mol\%) & $70^{\circ} \mathrm{C}$ & $2 \mathrm{~h}$ & 100 & 50 \\
\hline 8 & 3-Bpin (1 mol\%) & $70^{\circ} \mathrm{C}$ & $2 \mathrm{~h}$ & 57 & 29 \\
\hline 9 & 3-BMes $2(0.1 \mathrm{~mol} \%)$ & $70{ }^{\circ} \mathrm{C}$ & $4 \mathrm{~h}$ & 1000 & 250 \\
\hline 10 & 3-BMes $2(0.05 \mathrm{~mol} \%)$ & $70^{\circ} \mathrm{C}$ & $20 \mathrm{~h}$ & 1980 & 99 \\
\hline 11 & $1(1 \mathrm{~mol} \%)$ & $70^{\circ} \mathrm{C}$ & $2 \mathrm{~h}$ & $<2$ & $<1$ \\
\hline 12 & 2-BMes 2 (1 mol\% $)$ & $70^{\circ} \mathrm{C}$ & $2 \mathrm{~h}$ & 0 & 0 \\
\hline
\end{tabular}

[a] reactions performed in J-Young tubes; monitored by NMR spectroscopy with $0.0048 \mathrm{mmol}$ of catalyst, $0.48 \mathrm{mmol}$ of 9 -BBN in $d_{8}$-THF $(0.40 \mathrm{~mL})$ and exposed to an atmosphere of $\mathrm{CO}_{2}$ (1 bar), [b] The TON is obtained by ${ }^{1} \mathrm{H}$ NMR monitoring $\left(\mathrm{CH}_{3} \mathrm{O}-\mathrm{BBN}\right.$ formation $)$, with mesitylene as internal standard.

Dialkylboranes, other than 9-BBN, were also tested as potential reductants. As expected, the hydroboration of $\mathrm{CO}_{2}$ with catecholborane is slower than with 9-BBN because of the lower Lewis acidity of the borane. In fact, under the optimized reaction conditions $\left(48 \mathrm{~h}\right.$ at $70{ }^{\circ} \mathrm{C}$ ), 3-BMes2 promotes the reduction of $\mathrm{CO}_{2}$ to $\mathrm{MeOBcat}$ with a modest TOF of 23. Replacing catecholborane with $\mathrm{BH}_{3} \mathrm{SMe}_{2}$ did not lead to any significant product formation.

Again, replacing the BMes2 unit with a Bpin fragment somewhat slows down the catalytic reaction and a TOF of $3.0 \mathrm{~h}^{-1}$ is measured with 3-Bpin, at $25^{\circ} \mathrm{C}$ (vs $3.6 \mathrm{~h}^{-1}$ for $\mathrm{BMes}_{2}$ ). The difference of reactivity between 3-BMes2 and 3-Bpin is more pronounced at $70{ }^{\circ} \mathrm{C}$, with TOFs values of 50 and $29 \mathrm{~h}^{-1}$, respectively (Entries 7-8 in Table 1). This behaviour directly follows from the Arrhenius rate law.

Previous studies by the groups of Stephan and Cantat have established that basic guanidines, N-heterocyclic carbenes and phosphines can promote the hydroboration of $\mathrm{CO}_{2}{ }^{6 \mathrm{f}},{ }^{11}$ Mechanistic and computational investigations have shown that basic catalysts proceed through the activation of the $\mathrm{B}-\mathrm{H}$ bond, by coordination of the Lewis base to the hydroborane. ${ }^{6 f}$ Therefore we propose here that the benefit of combining a trivalent phosphorus function with a remote Lewis acid, as in 3-BMes2, results from a concomitant H-transfer / boraneformate adduct formation, in the first step of the $\mathrm{CO}_{2}$ reduction process (Scheme 3 ). In this approach, linking together the Lewis acid and the Lewis base functions should reduce the volume of the nonproductive region of the conformational space between the catalysts 
and the substrates and thus increase further the reaction rates. ${ }^{12}$ In fact, experimentally, catalysts 3-BMes2 and 3-Bpin are about twice as reactive as the corresponding bimolecular systems at $25^{\circ} \mathrm{C}$. This difference of reactivity corresponds roughly to a decrease of ca. 1 $\mathrm{kcal} / \mathrm{mol}$ in activation energy, consistent with an entropic effect.

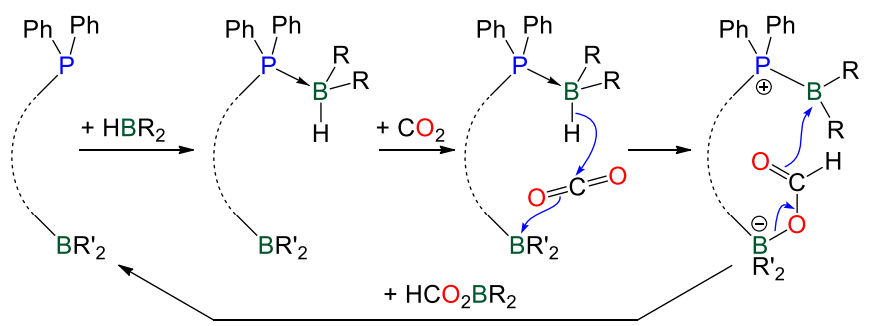

Scheme 3. Proposed synergistic effect of phosphino-borane catalysts in the hydroboration of $\mathrm{CO}_{2}$

Overall, we have demonstrated for the first time that the combination of phosphines and boranes offers a synergistic effect in the catalytic reduction of $\mathrm{CO}_{2}$ with hydroboranes. While the phosphine and the borane fragments, taken separately, do not catalyse the reduction of $\mathrm{CO}_{2}$, the $\mathrm{P} / \mathrm{B}$ derivatives 3 , combining the two functions, display high catalytic activity.

\section{Notes and references}

${ }^{a}$ NIMBE, CEA, CNRS, Université Paris-Saclay, Gif-sur-Yvette, France E-mail: thibault.cantat@cea.fr.

Fax: (+): (+33) 169086640

Homepage: http://iramis.cea.fr/Pisp/thibault.cantat/index.html.

${ }^{b}$ Institut de Chimie des Substances Naturelles, CNRS UPR 2301, Université Paris-Sud, Université Paris-Saclay, 1 av. de la Terrasse, 91198 Gif-sur-Yvette (France)

E-mail: arnaud.voituriez@cnrs.fr. angela.marinetti@cnrs.fr.

\section{Acknowledgements}

We thank the CHARMMMAT Laboratory of Excellence, CEA, CNRS, Institut de Chimie des Substances Naturelles, and the ANR for financial support. The European Research Council is acknowledged for an ERC Starting Grant to T.C (Grant Agreement no. 336467).

$\dagger$ Footnotes should appear here. These might include comments relevant to but not central to the matter under discussion, limited experimental and spectral data, and crystallographic data.

Electronic Supplementary Information (ESI) available: Fig. S1 and experimental procedures. See DOI: 10.1039/c000000x/

1 a) M. Aresta, Carbon Dioxide as Chemical Feedstock, Wiley-VCH, Weinheim, 2010; b) P. G. Jessop, T. Ikariya and R. Noyori, Chem. Rev., 1995, 95, 259; c) K. Huang, C. L. Sun and Z. J. Shi, Chem. Soc. Rev., 2011, 40, 2435; d) C. Federsel, A. Boddien, R. Jackstell, R. Jennerjahn, P. J. Dyson, R. Scopelliti, G. Laurenczy and M. Beller, Angew. Chem. Int. Ed., 2010, 49, 9777; e) C. Federsel, R. Jackstell and M. Beller, Angew. Chem, Int. Ed., 2010, 49, 6254; f) A. Tlili, X. Frogneux, E. Blondiaux and T. Cantat, Angew. Chem. Int. Ed., 2014, 53,
2543; g) A. Tlili, E. Blondiaux, X. Frogneux, and T. Cantat, Green. Chem., 2015, 17, 157; h) C. A. Huff and M. S. Sanford, J. Am. Chem. Soc., 2011, 133, 18122; i) K. Tominaga, Y. Sasaki, M. Kawai, T. Watanabe and M. Saito, Chem. Commun., 1993, 629; j) S. Wesselbaum, T. V. Stein, J. Klankermayer and W. Leitner, Angew. Chem. Int. Ed., 2012, 51, 7499; k) S. Savourey, G. Lefèvre, J.-C. Berthet, P. Thuéry, C. Genre and T. Cantat, Angew. Chem. Int. Ed., 2014, 53, 10466; 1) S. Wesselbaum, V. Moha, M. Meuresch, S. Brosinski, K. M. Thenert, J. Kothe, T. vom Stein, U. Englert, M. Hölscher, J. Klankermayer and W. Leitner, Chem. Sci., 2015, 6, 693; m) S. Bontemps, Coord. Chem. Rev., 2016, 308, 117.

2 CRC Handbook of Chemistry and Physics, 92th ed., Ed. W. M. Haynes, D. R. Lide, The Chemical Rubber Co., 2011.

3 For a general recent review see: C. C. Chong and R. Kinjo, ACS Catal., 2015, 5, 3238 .

4 S. Chakraborty, J. Zhang, J. A. Krause, and H. Guan, J. Am. Chem. Soc., 2010, 132, 8872.

5 a) S. Bontemps, L. Vendier and S. Sabo-Etienne, Angew. Chem. Int. Ed., 2012, 51, 1671; b) S. Bontemps, and S. Sabo-Etienne, Angew. Chem. Int. Ed., 2013, 52, 10253.

6 a) M.-A. Courtemanche, M.-A. Légaré, L. Maron, and F.-G. Fontaine, J. Am. Chem. Soc., 2013, 135, 9326; b) M.-A. Courtemanche, M.-A. Légaré, L. Maron, and F.-G. Fontaine, J. Am. Chem. Soc., 2014, 136, 10708; c) F.-G. Fontaine, M.-A. Courtemanche, and M.-A. Légaré, Chem. Eur. J., 2014, 11, 2990; d) M.-A. Légaré, M.-A. Courtemanche and F.-G. Fontaine, Chem. Commun., 2014, 50, 11362, e) R. Declercq, G. Bouhadir, D. Bourissou, M.-A. Légaré, M.-A. Courtemanche, K. S. Nahi, N. Bouchard, F.-G. Fontaine, and L. Maron, ACS Catal., 2015, 5, 2513; f) C. Das Neves Gomes, E. Blondiaux, P. Thuéry and T. Cantat, Chem. Eur. J., 2014, 20, 7098; g) T. Cantat, C. Gomes, E. Blondiaux, O. Jacquet, patent WO2014162266 filed April 3, 2013.

7 a) E. Blondiaux, J. Pouessel and T. Cantat, Angew. Chem. Int. Ed. 2014, 53, 12186; b) T. Wang and D. W. Stephan, Chem. Commun., 2014, 50, 7007; c) S. Y.-F. Ho, C.-W. So, N. Saffon-Merceron and N. Mézailles, Chem. Commun., 2015, 51, 2107.

8 a) M. W. P. Bebbington, S. Bontemps, G. Bouhadir, M. J. Hanton, R. P. Tooze, H. Van Rensburg and D. Bourissou, New J. Chem., 2010, 34, 1556. For some applications of phosphino-borane compounds in catalysis, see: b) S. Bontemps, G. Bouhadir, K. Miqueu, D. Bourissou J. Am. Chem. Soc. 2006, 128, 12056; c) S. Porcel, G. Bouhadir, N. Saffon, L. Maron, D. Bourissou, Angew. Chem., Int. Ed., 2010, 49, 6186. For other phosphino-boranes based on a ferrocene backbone, see: a) I. R. Morgan, A. Di Paolo, D. Vidovic, I. A. Fallis and S. Aldridge, Chem. Commun., 2009, 7288. b) X. Wang, G. Kehr, C.G. Daniliuc, and G. Erker, J. Am. Chem. Soc., 2014, 136, 3293.

9 a) D. A. Khobragade, S. G. Mahamulkar, L. Pospíšil, I. Císařová, L. Rulíšek, U. Jahn, Chem. Eur. J., 2012, 18, 12267; b) R. Sanders, U. T. Mueller-Westerhoff, J. Organomet. Chem., 1996, 512, 219.

10 Similarly, no adduct forms when $\mathbf{3}-\mathbf{B M e s}_{\mathbf{2}}$ is reacted with a stoichiometric amount of 9-BBN.

11 T. Wang and D. W. Stephan, Chem. Eur. J., 2014, 20, 3036.

12 S. Milstien and L. Cohen, J. Am. Chem. Soc., 1972, 94, 9158. 